Çiğdem Erdal

Yusuf Tunalı

Özlem Korkmaz Dilmen

Fatma Eren Akçıl

Ercüment Yentür

Mois Bahar

\section{Yoğun Bakım Ünitesinde Yatan Hastaların Yakınlarının Memnuniyetinin Değerlendirilmesi}

\author{
Evaluation of the Satisfaction of Patients' Relatives in \\ the Intensive Care Unit
}

Geliş Tarihi/Received: 13.07.2013

Kabul Tarihi/Accepted: 20.08.2013

Türk Yoğun Bakım Derneği Dergisi, Galenos Yayınevi tarafindan basılmıştır.

Journal of the Turkish Society of Intensive Care, published by Galenos Publishing.

ISNN: 1300-5804

Ciğdem Erdal(凶), Yusuf Tunalı,

Özlem Korkmaz Dilmen, Fatma Eren Akçll,

Istanbul Üniversitesi Cerrahpaşa Tıp Fakültesi,

Anesteziyoloji ve Reanimasyon Anabilim Dalı,

Istanbul, Türkiye

Ercüment Yentür,

Istanbul Bilim Üniversitesi Tıp Fakültesi, Anesteziyoloji

ve Reanimasyon Anabilim Dalı, Istanbul, Türkiye

Mois Bahar

Amerikan Hastanesi, Anesteziyoloji ve Reanimasyon

Departmanı, Istanbul, Türkiye

E-posta: cheyik@gmail.com

Gsm.: +90 5353905752
ÖZET Amaç: Yoğun bakım ünitelerinin (YBÜ) kalitelerinin belirlenmesi ve iyileştirilmesi için verilen hizmet değerlendirilmelidir. Anabilim Dalı'mızın YBÜ'lerinde bu yönde daha önce kapsamlı bir araștırma yapılmadığından hasta yakınlarının memnuniyetinin değerlendirilmesi amacıyla bir anket formu hazırlanmıștır.

Gereç ve Yöntem: Temmuz 2012-Mart2013 tarihleri arasında I.Ü. C.T.F. Anesteziyoloji ve Reanimasyon Anabilim Dalı YBÜ'lerinde en az 3 gün yoğun bakımda yatan hastaların yakınlarının memnuniyetinin değerlendirilmes anket uygulamasıyla incelenmiştir. Toplamda 211 adet anket hasta yakınları tarafından doldurulmuştur (cevaplanma oranı \%52,6). Bulgular: Anketimizin sonuçlarına göre hasta yakınları hastalarının bakım ve tedavisinden, verilen bilgiden, kendilerine gösterilen ilgiden, karar verme sürecinden iyi derecede memnun bulunmuşlar, hastalarının durumunu ve yoğun bakım koşullarını iyi derecede algılayabilmişlerdir. Hasta yakınları duygularına gösterilen ilgiden orta derecede, yoğun bakım ünitesinin bekleme ortamından zayıf derecede memnun olmuşlardır.

Sonuç: Çalışmamızda YBÜ çalışanlarının bilgi, beceri ve tutum açısından başarılı oldukları görülmektedir. Bunun yanında bekleme alanı koșullarının düzeltilmesi gerektiğini düşünmekteyiz.

Anahtar Kelimeler: Yoğun bakım ünitesi, hasta yakını memnunyeti, anket
SUMMARY Objective: The health service given needs to be assessed for defining and improving the quality of intensive care units (ICU). In the ICUs of our department, because no extensive research in this field has been made previously, we aimed to evaluate satisfaction with a questionnaire. Material and Method: Through July 2012March 2013, satisfaction of the family members of patients presenting more than 3 days has been investigated via a questionnaire in the ICUs of Anesthesiology and Reanimation Department of Istanbul University Cerrahpasa Medicine Faculty. In total, 211 number of questionnaires have been answered by family members (Respond rate \%52.6).

Results: Family members are found to be well satisfied with the treatment and care of their patients, information given, concern shown to them and the decision making process. They are also able to perceive the condition of their patient and the conditions of the ICU in high grade. Family members are found to be moderately satisfied with the interest shown to their feelings and weakly satisfied with the waiting room.

Conclusion: Staffs of the ICU are seemed to be successful in knowledge, skill and behaviour. Besides, we think that waiting room conditions are required to be improved.

Key Words: Intensive care unit, family satisfaction, questionnaire 


\section{Giriș}

Dünyada sağlık sektöründe özelleşme ve sağlık sigortalarının yaygınlaşması ile birlikte, verilen sağlık hizmetinin kalitesinin değerlendirilmesi önem kazanmış, kalitenin değerlendirilmesinde de memnuniyetin ölçülmesi kilit rol oynamıştır. Tıp ve teknolojideki gelişmelerle birlikte ortalama yaşam süresinin uzaması, tanı ve tedavi yöntemlerinin artması, bunların sonucunda yoğun bakım intiyacı olan hasta sayısında da artış meydana gelmesi ile yoğun bakım ünitelerinde kalite değerlendirmeleri önem kazanmıştır. Başlangıçta kalite değerlendirmesi amacıyla yatan hastaların yalnızca mortalite, yatış süresi ve fonksiyonel durumları göz önünde bulundurulmuş, ilerleyen zamanlarda ise yoğun bakım ünitelerinde memnuniyet de değerlendirilmeye başlamıştır (1-4). Ancak yoğun bakımda yatmakta olan hastaların büyük çoğunluğu kritik hastalardır ve şuur durumlarındaki değişiklikler nedeni ile kendi bakım ve tedavileri ile ilgili değerlendirme yapamayacak durumdadırlar. Onların yerine bu değerlendirmeler ve karar verme aşamaları hastaların yakınları tarafından yapılmaktadır. Böylelikle, hasta yakınlarının memnuniyet değerlendirmeleri, yoğun bakım ünitelerinde verilen sağlık hizmetinin kalitesinin sorgulanmasında önemli ölçütlerden biri olmuştur (3,5-11).

Anabilim Dalı'mızın yoğun bakım ünitelerinde daha önce bu yönde kapsamlı bir memnuniyet araştırmasının yapılmamış olduğunun görülmesi üzerine bir anket formu hazırlanarak, hastanın tedavisi ve bakımı, hasta hakkında verilen bilginin niteliği, yoğun bakım ünitesi çalışanlarının hasta yakınına olan tutumları, bekleme salonunun koşulları ve karar verme süreci ile ilgili memnuniyetin değerlendirilmesi amaçlanmıştır.

\section{Gereç ve Yöntem}

Hastanemiz etik kurulundan onay alındıktan sonra Temmuz 2012-Mart 2013 tarihleri arasında I.Ü. Cerrahpaşa Tıp Fakültesi Anesteziyoloji ve Reanimasyon Anabilim Dalı'na bağlı 3. düzey yoğun bakım ünitelerinde (Sadi Sun YBÜ, Acil YBÜ, Nöroşirürji YBÜ) en az 3 gün yoğun bakımda yatan hastaların yakınlarının memnuniyetinin değerlendirilmesi anket uygulaması ile incelendi.

Anketi hazırlarken çoğunlukla daha önce Kanada'da yapılmış çok merkezli araştırmadan yararlanıldı (9). FS-ICU 24 başlığı altında uygulanmış olan anketteki sorulardan araştırmamıza uygun olanlar seçilerek Türkçeye çevrildi. Bazı sorular da anabilim dalımıza bağlı yoğun bakım ünitelerindeki ilgili öğretim üyeleri ile yapılan görüşmeler sonucunda oluşturuldu. Çoktan seçmeli sorular haricinde hasta yakınlarının hastalarını ziyaret ederken kendilerini rahatsız eden bir durumla karşılaşıp karşılaşmadıklarını sorgulayan ve yazarak yanıtlanması gereken bir soru da eklendi. Hazırlanmış olan anketler, hastaların yoğun bakım ünitesinde yatışının üçüncü veya daha sonraki günlerinde ve hastalar yoğun bakımda yatmakta iken yakınlarının onamları alındıktan sonra uygulandı. Her hasta için sadece bir yakınına anket verildi ve hasta yakını tarafından doldurulduktan sonra geri alındı. Anket hastayı en çok ziyaret eden ve en çok bilgi alan yakınına uygulandı. Çalışmaya katılmayı kabul etmeyen hasta yakınları ile yoğun bakım ünitesinde üç günden daha kısa süre yatan hastaların yakınları çalışmaya alınmadı.

Anketin ilk bölümü hasta yakını özelliklerinin belirlendiği sorulardan oluşturuldu. Bu bölümde hasta yakının yaşı, cinsiyeti, hasta ile olan yakınlık derecesi, daha önce yoğun bakımda yatan yakınının olup olmaması, hasta ile birlikte yaşayıp yaşamadığı veya ne sıkıkla görüştükleri, hastanenin bulunduğu şehirde ikamet edip etmediği ve eğitim düzeyi sorgulandı. Memnuniyetin sorgulandığı diğer 7 bölüm ise hasta yakınlarının memnuniyetinin değerlendirildiği bölümler olarak hazırlandı. Bu bölümler ise sırasıyla 1) Hastanın bakım ve tedavisi, 2) Hasta yakınlarına verilen bilginin sıklığı, almanın kolaylığı, anlaşılabilirliği, güvenilirliği, tutarıı̆ı̆ı, 3) Hasta yakınının yoğun bakım ünitesinin çalışma düzenini algılaması, 4) Yoğun bakım ünitesi çalışanlarının hasta yakınına karşı olan tutumları, 5) Yoğun bakım ünitesi çalışanlarının hasta yakınlarının duygularına gösterdiği ilgi 6) Yoğun bakım ünitesinin fiziki koşulları ve son olarak 7) Hasta yakınının hastası ile ilgili alması gereken kararlar sürecinde yoğun bakım ünitesi çalışanlarııın hasta yakınına yaklaşımları şeklindedir.

Uygulanması gereken anket sayısı belirlenirken yoğun bakım ünitelerinde çalışmanın yapıldığı 9 aylık sürede 3 gün veya daha uzun süre yoğun bakım ünitesinde yatan hastaların toplam sayıları elde edildi. Buna göre hasta sayıları Sadi Sun YBÜ'de 252, Acil YBÜ'de 92, Beyin Cerrahisi YBÜ'de 57 olarak belirlendi. Örneklem hesabı yapılarak uygulanması gereken minimum anket sayısı 152 olarak saptandı.

$$
\mathrm{n}=\frac{\mathrm{N} \mathrm{t}^{2} \mathrm{pq}}{\mathrm{d}^{2}(\mathrm{~N}-1)+\mathrm{t}^{2} \mathrm{pq}}
$$

$\mathrm{N}$ : Evrendeki birey sayısı

n: Örnekleme alınacak birey sayısı

p: Incelenen olayın görülüş sıklığı

q: Incelenen olayın görülmeyiş sıklığı

t: Belirli serbestlik derecesinde ve saptanan yanılma düzeyinde $t$ tablosundan bulunan teorik değer

d: Olayın görülüş sıklığına göre yapılmak istenen \pm sapma $\mathrm{n}=\frac{(401)(1.96)^{2}(0.20)(0.80)}{(0.05) 2(401-1)+(1.96)^{2}(0.20)(0.80)}$

$\mathrm{n}=152$ (Minimum olgu miktarı 152)

Çalışmada elde edilen bulgular değerlendirilirken, istatistiksel analizler için lisanslı olan NCSS (Number Cruncher Statistical System) 2007\&PASS (Power Analysis and Sample Size) 2008 Statistical Software (Utah, USA) programı kullanıldı. Çalışma verileri değerlendirilirken tanımlayıcı istatistiksel metodların (Ortalama, Standart sapma, ortanca, sıklık, oran) yanı sıra niceliksel verilerin karşısştııımasında normal dağılım göstermeyen parametrelerin gruplar arası 
karşılaştırmalarında "Kruskal Wallis" testi ve farklılığa neden olan grubun tespitinde "Mann-Whitney $U$ " testi kullanıldı. Yine normal dağılım göstermeyen parametrelerin iki grup arası karşılaştırmalarında da "Mann-Whitney U" testi kullanıldı. Memnuniyet puanları ile yaş arasındaki ilişki analizi için "Spearman'ın rho" korelasyon katsayısı kullanıldı. Anket geçerlik-güvenirlik çalışmasında "Cronbach'ın alfa" katsayısı kullanıldı. Sonuçlar \%95'lik güven aralığında, anlamlılık $p$ $<0,05$ düzeyinde değerlendirildi.

\section{Bulgular}

Temmuz 2012 - Mart 2013 tarihleri arasında yapılmış olan çalışma süresince üç gün veya daha uzun süreli yoğun bakımda yatan hasta sayıları; Sadi Sun YBÜ'de 252 olarak bulunmuş olup bunlardan 123 hastanın yakını, Acil YBÜ'de 92 olarak bulunmuş olup bunlardan 65 hastanın yakını, Beyin Cerrahisi YBÜ'de 57 olarak bulunmuş olup bunlardan 23 hastanın yakını verilen anket formlarını doldurarak teslim etmiştir. Tüm yoğun bakımlardan toplamda 211 adet anket, onam formu doldurulmuş ve tüm soruları cevaplanmış olarak geri teslim alınmıştır. Cevaplanma oranı \%52,6 olarak bulunmuştur.

Anket formlarını dolduran hasta yakınlarının yaşları 18 ile 62 arasında değişmekte olup yaş ortalamaları $42,46 \pm 9,76$ yıl olarak bulundu.

Hasta yakınlarının demografik verileri Tablo 1'de gösterilmektedir.

Memnuniyet değerleri hesaplanmadan önce tüm bölümler için geçerlik güvenirlik çalışması yapıldı ve buna göre tüm bölümler oldukça veya yüksek derecede güvenilir bulundu. Sonrasında hasta yakınlarının yanıtlarına göre memnuniyet dereceleri 0 ile 100 arasında puanlara çevrildi. En yüksek memnuniyet puanı 87,29 $\pm 13,62$ puan ile "Hastanın bakımı ve tedavisi" bölümünde, en düşük memnuniyet puanı ise 33,38 22,71 puan ile "Yoğun Bakım Ünitesi Bekleme Ortamı ve Lojistik Destek" bölümünde ölçüldü. Bölümlerin memnuniyet puanları Tablo 2' de verilmiştir.

Memnuniyetin sorgulandığı bölümlere tek tek bakıldığında, en yüksek memnuniyet puanı "Hastanın Bakım ve Tedavisi" bölümünde ölçülmüştür. Bu bölümde hasta yakınlarının yarıdan fazlası hastalarının bakım ve tedavileri ile ilgili soruları olumlu değerlendirmişler ve hastalarının ziyaretleri sırasında kendilerini rahatsız edecek bir durumla karşılaşmadıklarını ifade etmişlerdir. Bu bölüme ait hasta yakınlarının verdikleri yanıtlar Tablo 3'te gösterilmiştir.

Ankette ikinci bölüm olan "Hasta Yakınının Bilgilendirilmesi" bölümünde bilgilendirilme ile ilgili sorulara verilen yanıtlar hasta yakınlarının büyük çoğunluğu tarafından olumlu olarak değerlendirilmiştir. Bu bölüme ait değerler Tablo 4'te gösterilmiştir.
Tablo 1. Hasta yakınlarının demografik özelliklerin dağılımı

\begin{tabular}{|c|c|c|c|}
\hline & & $\mathbf{N}$ & $\%$ \\
\hline \multirow{2}{*}{ Cinsiyeti } & Kadın & 91 & 43,1 \\
\hline & Erkek & 120 & 56,9 \\
\hline \multirow{6}{*}{ Yakınlık Derecesi } & Eş & 71 & 33,6 \\
\hline & Ebeveyn & 9 & 4,3 \\
\hline & Kardeş & 39 & 18,5 \\
\hline & Çocuk & 84 & 39,8 \\
\hline & İkinci Derece Akraba & 6 & 2,8 \\
\hline & Diğer & 2 & 0,9 \\
\hline \multirow{2}{*}{$\begin{array}{l}\text { Daha Önce Yoğun } \\
\text { Bakımda Yatan } \\
\text { Akraba Varlığı }\end{array}$} & Var & 111 & 52,6 \\
\hline & Yok & 100 & 47,4 \\
\hline \multirow{2}{*}{$\begin{array}{l}\text { Hasta ile Birlikte } \\
\text { Yaşama Durumu }\end{array}$} & Evet & 121 & 57,3 \\
\hline & Hayır & 90 & 42,7 \\
\hline \multirow{4}{*}{$\begin{array}{l}\text { Hasta ile Birlikte } \\
\text { Yaşamayan Yakının } \\
\text { Hasta ile Görüşme } \\
\text { Sıklığı }\end{array}$} & $\begin{array}{l}\text { Haftada bir kereden } \\
\text { fazla }\end{array}$ & 30 & 33,3 \\
\hline & Haftada bir kez & 30 & 33,3 \\
\hline & Ayda bir kez & 28 & 31,2 \\
\hline & Yılda bir kez & 2 & 2,2 \\
\hline \multirow[t]{2}{*}{ Yaşanılan Yer } & $\begin{array}{l}\text { Hastanenin bulunduğu } \\
\text { şehirde }\end{array}$ & 141 & 66,8 \\
\hline & Şehir dışında & 70 & 33,2 \\
\hline \multirow{4}{*}{ Eğitim Düzeyi } & Okuma/Yazma Yok & 3 & 1,4 \\
\hline & illköğretim & 71 & 33,6 \\
\hline & Lise & 60 & 28,4 \\
\hline & Üniversite & 77 & 36,5 \\
\hline
\end{tabular}

Tablo 2. Bölümlerden hesaplanan puanların dağılımı

\begin{tabular}{lll}
\hline & Min-Maks & Ort \pm SD \\
\hline Hastanın Bakım ve Tedavisi & $46,67-100,0$ & $87,29 \pm 13,62$ \\
Hasta Yakının Bilgilendirilmesi & $33,33-100,0$ & $77,43 \pm 19,59$ \\
Algılama & $44,44-100,00$ & $85,94 \pm 16,71$ \\
Hasta Yakınına İlgi & $11,11-100,0$ & $75,09 \pm 22,33$ \\
$\begin{array}{l}\text { Hasta Yakınının } \\
\text { Duygusallı̆ına Etki }\end{array}$ & $0,0-100,0$ & $59,27 \pm 25,52$ \\
$\begin{array}{l}\text { Yoğun Bakım Ünitesi Bekleme } \\
\text { Ortamı ve Loj. Destek }\end{array}$ & $0,0-100,0$ & $33,38 \pm 22,71$ \\
Karar Verme Süreci & $0,0-100,0$ & $70,14 \pm 26,43$ \\
\hline
\end{tabular}

Memnuniyetin sorgulandığı üçüncü bölüm "Algılama" bölümüdür. Bu bölümde yer alan sorulara verilen yanıtlara bakıldığında hasta yakınlarının büyük çoğunluğunun hastalarının durumu ve yoğun bakım ünitesi ile ilgili konuları iyi derecede algılayabildikleri görülmüştür. Tablo 5 'te bu bölüm ile ilgili yanıtlar görülmektedir.

Memnuniyetin sorgulandığı dördüncü bölüm olan "Hasta Yakınına Illgi" bölümünde hasta yakınlarının yarıdan fazlasının yoğun bakım ünitesi çalışanları tarafından kendilerine karşı gösterilen ilgiden memnun oldukları görülmüştür. Hasta yakınına ilgi bölümüne verilen yanıtlar Tablo 6'da gösterilmiştir. 


\section{Tablo 3. Hastanın bakım ve tedavisi}

\begin{tabular}{llll}
\hline & & $\mathbf{n}$ & $\%$ \\
Yoğun bakım ünitesi çalışanlarının & Çok İyi & 142 & 67,3 \\
hastanızı önemsediğini düşünüyor & İyi & 60 & 28,4 \\
musunuz? & Orta & 9 & 4,3 \\
& Zayıf & 0 & 0 \\
Hastanıza uygulanan tedavinin & Çok l̇yi & 142 & 67,3 \\
eksiksiz yapıldı̆ına güven duyuyor & İyi & 66 & 31,3 \\
musunuz? & Orta & 3 & 1,4 \\
& Zayıf & 0 & 0 \\
Hastanızı ziyaret ettiğinizde & Hiçbir Zaman & 136 & 64,5 \\
sizi rahatsız eden bir durumla & Bazen & 71 & 33,6 \\
karşıllaşınız mı? & Çoğu Zaman & 4 & 1,9 \\
& Her Zaman & 0 & 0 \\
Hemşirelerin beceri ve yeteneklerini & Çok İyi & 117 & 55,5 \\
nasıl değerlendirirsiniz? & İyi & 82 & 38,9 \\
& Orta & 9 & 4,3 \\
& Zayıf & 3 & 1,4 \\
Doktorların beceri ve yeteneklerini & Çok l̇yi & 147 & 69,7 \\
nasıl değerlendirirsiniz? & İyi & 64 & 30,3 \\
& Orta & 0 & 0 \\
& Zayıf & 0 & 0 \\
\hline
\end{tabular}

Memnuniyetin sorgulandığı beşinci bölüm "Hasta Yakınının Duygusallığına Etki" bölümüdür. Bu bölümde hasta yakınlarının büyük çoğunluğunun duygularına gösterilen ilgiden memnun olmadığı, ancak bunun yanında yine büyük çoğunluğunun sıkıntı duydukları konuları paylaşmada problem yaşamadığı görülmüştür. Bu bölüme ait yanıtlar Tablo 7'de gösterilmiştir.

Memnuniyetin değerlendirildiği altıncı bölüm "Yoğun Bakım Ünitesi Bekleme Ortamı ve Lojistik Destek" bölümüdür. Bu bölüm en düşük memnuniyet puanının ölçüldüğg̈ bölümdür. Hasta yakınlarının yarıya yakını tarafından bekleme salonunun konforu zayıf olarak değerlendirmiş, büyük çoğunluğu tarafından intiyaçlarını karşılamada sıkıntı çektikleri ve hastaları ile ilgili yoğun bakım ünitesi dışındaki birimlerde yapılması gereken işler için bizzat ilgilenmek zorunda kaldıklarını belirtmişlerdir. Bu bölüme ait sorular ve yanıtları Tablo 8'de gösterilmiştir.

Ankette memnuniyetin değerlendirildiği son bölüm "Karar verme süreci" bölümüdür. Hasta yakınlarının yarıdan fazlası bu sürece dahil edildiğini, desteklendiğini, karar vermek için yeterli sürenin kendine tanındığını belirtmiş̧lerdir. Bu bölümle ilgili yanıtlar Tablo 9'da gösterilmiştir.

\section{Tartışma}

Çalışmamızda yoğun bakım ünitelerinde verilen sağlık hizmetinin kalitesini bu ünitelerde yatan hastaların yakınlarına memnuniyet anketi uygulayarak değerlendirdik.
Tablo 4. Hasta yakınının bilgilendirilmesi

\begin{tabular}{|c|c|c|c|}
\hline & & $\mathbf{n}$ & $\%$ \\
\hline \multirow{4}{*}{$\begin{array}{l}\text { Hastanızın durumu hakkında } \\
\text { size verilen bilginin sıkığını nasıl } \\
\text { değerlendirirsiniz? }\end{array}$} & Çok İyi & 78 & 37,0 \\
\hline & İyi & 91 & 43,1 \\
\hline & Orta & 27 & 12,8 \\
\hline & Zayif & 15 & 7,1 \\
\hline \multirow{4}{*}{$\begin{array}{l}\text { Hastanız hakkında bilgi almanın } \\
\text { kolaylığını nasıl değerlendirirsiniz? }\end{array}$} & Çok Iyi & 66 & 31,3 \\
\hline & İyi & 90 & 42,7 \\
\hline & Orta & 52 & 24,6 \\
\hline & Zayif & 3 & 1,4 \\
\hline \multirow{4}{*}{$\begin{array}{l}\text { Hastanız hakkında verilen bilginin } \\
\text { anlaşılabilirliğini nasıl değerlendirirsiniz? }\end{array}$} & Çok İyi & 91 & 43,1 \\
\hline & İyi & 90 & 42,7 \\
\hline & Orta & 27 & 12,8 \\
\hline & Zayif & 3 & 1,4 \\
\hline \multirow{4}{*}{$\begin{array}{l}\text { Hastanız hakkında verilen bilginin } \\
\text { güvenirliliğini nasıl değerlendirirsiniz? }\end{array}$} & Çok Iyi & 118 & 55,9 \\
\hline & İyi & 81 & 38,4 \\
\hline & Orta & 12 & 5,7 \\
\hline & Zayif & 0 & 0 \\
\hline \multirow{4}{*}{$\begin{array}{l}\text { Hastanız hakkında verilen bilgi, } \\
\text { öğrenmek istediğiniz her konuyu } \\
\text { içeriyor mu? }\end{array}$} & Çok Iyi & 115 & 54,5 \\
\hline & İyi & 57 & 27,0 \\
\hline & Orta & 39 & 18,5 \\
\hline & Zayif & 0 & 0 \\
\hline \multirow{4}{*}{$\begin{array}{l}\text { Hastanız hakkında hemşire ve } \\
\text { doktordan aldığınız bilgi aynı } \\
\text { doğrultuda mı? }\end{array}$} & Çok İyi & 119 & 56,5 \\
\hline & İyi & 65 & 30,6 \\
\hline & Orta & 24 & 11,5 \\
\hline & Zayif & 3 & 1,4 \\
\hline \multirow{4}{*}{$\begin{array}{l}\text { Hastanız hakkında bilgi alan aile } \\
\text { üyelerine aynı bilgi mi veriliyor, yoksa } \\
\text { yapılan açılamalarda farklı şeyler mi } \\
\text { söyleniyor? }\end{array}$} & Çok İyi & 130 & 61,6 \\
\hline & İyi & 69 & 32,7 \\
\hline & Orta & 12 & 5,7 \\
\hline & Zayif & 0 & 0 \\
\hline
\end{tabular}

Tablo 5. Algilama

\begin{tabular}{|c|c|c|c|}
\hline & & $n$ & $\%$ \\
\hline \multirow{4}{*}{$\begin{array}{l}\text { Hastanızın takip ve tedavisinin servis } \\
\text { şartlarında yapılması yerine neden yoğun } \\
\text { bakım ünitesinde yapıldığını anlıyor } \\
\text { musunuz? }\end{array}$} & Çok İyi & 169 & 80,1 \\
\hline & İyi & 39 & 18,5 \\
\hline & Orta & 3 & 1,4 \\
\hline & Zayif & 0 & 0 \\
\hline \multirow{4}{*}{$\begin{array}{l}\text { Hastanıza ne olduğunu ve yapılanların } \\
\text { neden yapıldığını anliyor musunuz? }\end{array}$} & Çok Iyi & 133 & 63,0 \\
\hline & İyi & 66 & 31,3 \\
\hline & Orta & 12 & 5,7 \\
\hline & Zayif & 0 & 0 \\
\hline \multirow{4}{*}{$\begin{array}{l}\text { Yoğun bakım ünitesini koşullarını ve } \\
\text { çalışma düzenini anlıyor musunuz? }\end{array}$} & Çok Iyi & 109 & 51,7 \\
\hline & İyi & 72 & 34,1 \\
\hline & Orta & 30 & 14,2 \\
\hline & Zayif & 0 & 0 \\
\hline
\end{tabular}


Tablo 6. Hasta yakınına ilgi

\begin{tabular}{llll}
\hline & & $\mathbf{n}$ & $\%$ \\
\hline Çalışanlar size karşı kibar ve anlayışıı & Çok İyi & 127 & 60,2 \\
davranıyorlar mı? & İyi & 45 & 21,3 \\
& Orta & 39 & 18,5 \\
& Zayıf & 0 & 0 \\
Hastanızın durumunda önemli & Çok İyi & 123 & 58,3 \\
herhangi bir değişiklik olduğunda & İyi & 58 & 27,5 \\
birini sizi evden arayacağına inanıyor & Orta & 18 & 8,5 \\
musunuz? & Zayıf & 12 & 5,7 \\
& Kesinlikle & 84 & 39,8 \\
Bekleme alanında kendinizi terk & hayır & 64 & 30,3 \\
edilmiş veya yalnız hissediyor & Bazen & 33 & 15,6 \\
musunuz? & Çoğu zaman & 33 & 14,2 \\
\hline
\end{tabular}

Tablo 7. Hasta yakınının duygusallığına etki

\begin{tabular}{|c|c|c|c|}
\hline & & $n$ & $\%$ \\
\hline \multirow{4}{*}{$\begin{array}{l}\text { Yoğun bakım ünitesi hemşirelerinden } \\
\text { biri şu anki duygularınızla ilgilendi mi? }\end{array}$} & Çok İyi & 42 & 19,9 \\
\hline & İyi & 21 & 10,0 \\
\hline & Orta & 51 & 24,2 \\
\hline & Zayıf & 97 & 46,0 \\
\hline \multirow{4}{*}{$\begin{array}{l}\text { Yoğun bakım ünitesi doktorlarından } \\
\text { biri şu anki duygularınızla ilgilendi mi? }\end{array}$} & Çok Iyi & 51 & 24,2 \\
\hline & İyi & 54 & 25,6 \\
\hline & Orta & 42 & 19,9 \\
\hline & Zayıf & 64 & 30,3 \\
\hline \multirow{4}{*}{$\begin{array}{l}\text { Hastanızı ziyaret ederken kendinizi } \\
\text { rahat hissediyor musunuz? }\end{array}$} & Çok Iyi & 81 & 38,4 \\
\hline & İyi & 79 & 37,4 \\
\hline & Orta & 45 & 21,3 \\
\hline & Zayif & 6 & 2,8 \\
\hline \multirow{4}{*}{$\begin{array}{l}\text { Sizi üzen ve sıkıntı duyduğunuz } \\
\text { konuları yoğun bakım hemşireleri ile } \\
\text { paylaşabiliyor musunuz? }\end{array}$} & Çok Iyi & 84 & 39,8 \\
\hline & İyi & 73 & 34,6 \\
\hline & Orta & 30 & 14,2 \\
\hline & Zayıf & 24 & 11,4 \\
\hline \multirow{4}{*}{$\begin{array}{l}\text { Sizi üzen ve sıkıntı duyduğunuz } \\
\text { konuları yoğun bakım doktorları ile } \\
\text { paylaşabiliyor musunuz? }\end{array}$} & Çok Iyi & 112 & 53,1 \\
\hline & İyi & 66 & 31,3 \\
\hline & Orta & 12 & 5,7 \\
\hline & Zayıf & 21 & 10,0 \\
\hline
\end{tabular}

Çalışmamız süresince yoğun bakım ünitelerimizde 401 hastanın üç gün ve daha uzun süreli yatışı oldu, bunlardan toplamda 211 hastanın yakınından veriler elde edilebildi. Böylece hastalarımızın \% 52,6'sına anket ile ulaşılabildi. Bu sonuç diğer çalışmalarla karşılaştırıldığında oldukça düşük bir katılım yüzdesini göstermektedir $(1,3,4,5,9)$. Buna etken olarak anket uygulaması sırasında bizim de karşılaştığımız, bir şeylerin düzelmeyeceğine dair önyargı ve hastalarının halen tedavilerinin devam etmekte olmasını gözlemledik.
Tablo 8. Yoğun bakım ünitesi bekleme ortamı ve lojistik destek

\begin{tabular}{llll}
\hline & & n & $\%$ \\
\hline Oturduğunuz bekleme salonu & Çok İyi & 27 & 12,8 \\
konforlu mu? & İyi & 42 & 19,9 \\
& Orta & 54 & 25,6 \\
& Zayıf & 88 & 41,7 \\
Bekleme salonu ihtiyaçlarınızı & Her Zaman & 30 & 14,2 \\
karşılayabiliyor mu? & Çoğu Zaman & 42 & 19,9 \\
& Bazen & 85 & 40,3 \\
& Kesinlikle Hayır & 54 & 25,6 \\
Yoğun bakım ünitesi dışında & Kesinlikle Hayır & 12 & 5,7 \\
hastanızla ilgili yapılması gereken & Bazen & 27 & 12,8 \\
işler için bizzat ilgilenmek & Çoğu Zaman & 66 & 31,3 \\
durumunda kalıyor musunuz? & Her Zaman & 106 & 50,2 \\
\hline
\end{tabular}

En yüksek puanın ölçüldüğü "Hastanın bakım ve tedavisi" bölümünde elde edilen sonuç (Memnuniyet puanı 100 üzerinden $87,29 \pm 13,62$ puan) tarafımızca oldukça başarıı bulunmuştur. Verilen yanıtlardan hasta yakınlarının büyük çoğunluğu tarafından, hastalarının önemsendiği, tedavilerinin eksiksiz yapıldığı, hemşire ve doktorların bilgi ve becerilerinin çok iyi olduğunu düşündükleri sonucu çıkarılabilir. Akıncı SB ve arkadaşlarının 2004 yılında ve Erden IA ve arkadaşlarının 2010 yılında yaptıkları çalışmalarda da hastaların bakım ve tedavisi ile ilgili memnuniyet değerlendirmesinde hasta yakınlarının yüksek derecede memnun olduğu (Memnuniyet puanı 100 üzerinden $86 \pm 11$ ve $87 \pm 9$ ) saptanmıştır $(8,12)$. Bu sonuçlar bizim bulgularımızla benzerdir. Hasta yakınlarının memnuniyeti ve güveni hastalarının ülkemizde iyi düzeyde ve bilimsel hizmet verdiği kabul edilen üniversite hastanelerinden birinde olmasından kaynaklanabilir. Farklı düzey hastaneleri arasında bu değerlendirmenin yapıldığı bir anket uygulaması olmadığı için bu bizim öngörümüzdür.

En yüksek geçerlik güvenirlik oranına sahip olan ve hasta yakınlarının memnuniyet değerlendirmesinde üçüncü sırada yüksek puan alan bölüm "Hasta yakınının bilgilendirilmesi" bölümüdür. Hasta yakınları tarafından, bilgi almanın kolaylığı ve verilen bilginin sıklığı iyi, içeriği yeterli, güvenilirliği ve tutarlılğı çok iyi olarak değerlendirilmiştir. Verilen bilginin anlaşılabilirliği ise çok yakın oranlarda çok iyi ve iyi olarak değerlendirilmiştir. Birçok çalışmada hasta yakınları tarafından verilen bilginin içeriği, anlaşılabilirliği ve sıklığı ile ilgili memnuniyet değerlendirmesi düşük olarak bulunmuş; bu konu üzerine memnuniyeti artırmak için daha ayrıntılı araştırmalar ve çalışmalar yapılması planlanmıştır $(3,4,8,10,12)$. Bu çalışmaların aksine çalışmamızda hasta yakınlarına verilen bilginin anlayabilecekleri şekilde, yeterli ve güvenilir olduğu görülmektedir. Bunun nedeni olarak hasta yakınlarına bilgilerin yalnızca hastası ile birebir ilgilenen yoğun bakım ünitesi sorumlu doktorları tarafından verilmesi olduğunu düşünmekteyiz. 


\begin{tabular}{|c|c|c|c|}
\hline & & $\mathbf{n}$ & $\%$ \\
\hline \multirow{2}{*}{$\begin{array}{l}\text { Hastanızın tedavisi ve bakımı ile ilgili karar verme aşamalarında, sizin } \\
\text { de bu sürece dahil edildiğinizi hissettiniz mi? }\end{array}$} & Çoğunlukla dahil edildim & 78 & 37,0 \\
\hline & Hiç dahil edilmedim & 24 & 11,4 \\
\hline \multirow{3}{*}{ Karar verme aşamasında kendinizi desteklenmiş hissettiniz mi? } & Oldukça desteklendim & 97 & 46,0 \\
\hline & Çok az desteklendim & 21 & 10,0 \\
\hline & Hiç desteklenmedim & 18 & 8,5 \\
\hline \multirow[b]{3}{*}{$\begin{array}{l}\text { Hastanızın tedavi ve bakımı üzerinde kontrol sahibi olduğunuzu } \\
\text { hissettiniz mi? }\end{array}$} & İyi derecede kontrol sahibi olduğumu hissettim & 78 & 37,0 \\
\hline & Biraz kontrol sahibi olduğumu hissettim & 52 & 24,6 \\
\hline & $\begin{array}{l}\text { Çok az kontrol sahibi olduğumu ve sağlık sisteminin } \\
\text { kontrolü ele aldığını hissettim }\end{array}$ & 51 & 24,2 \\
\hline \multirow{2}{*}{$\begin{array}{l}\text { Hastanızın tedavi ve bakımı ile ilgili karar verme aşamasında, } \\
\text { endişelerinizin giderilmesi ve sorunlarınızın yanıtlanması için yeterince } \\
\text { zamanınız oldu mu? }\end{array}$} & Yeterince zamanım oldu & 168 & 79,6 \\
\hline & Daha fazla zamana ihtiyacım vardı & 43 & 20,4 \\
\hline
\end{tabular}

Hasta yakınları tarafından ikinci sırada yüksek puan alan bölüm "Algılama" bölümüdür. Bu bölümde de hasta yakınları tarafından hastalarının neden yoğun bakım ünitesinde yatmakta olduğunun, hastasının hastalığının ve yapılan tedavilerin neler olduğunun ve yoğun bakım ünitesinin çalışma düzeninin çok iyi algılandığı anlaşılmaktadır. Daha önce yapılmış çalışmalarda bu konuda değerlendirmeye rastlanmamıştır. Çalışmamızda algılamayla ilgili yüksek olarak ölçülen memnuniyetin, hasta yakınlarına verilen bilginin niteliğinin iyi olması sayesinde gerçekleştiği düşünülmektedir.

Memnuniyet değerlendirilmesinde puanlamaya göre dördüncü sırada "Hasta yakınına ilgi" bölümü gelmektedir. Bu bölümde hasta yakınlarının yarıdan fazlası yoğun bakım çalışanlarının kendilerine davranışlarının çok iyi olduğunu, hastalarının durumunda önemli bir değişiklik olması halinde aranarak haber verileceğine güven duyduklarını belirtmişlerdir. Ayrıca hasta yakınlarından yarıya yakını da kendilerini bekleme ortamında yalnız hissetmediklerini ifade etmişlerdir. Bu sonuçlar tarafımızdan tatminkar olarak değerlendirilmiştir. Bu sonuçları karşılaştıracağımız bir çalışma bulunmadığından bu durumun nedenleri arasında, bekleme ortamında yoğun bakım ünitesinde yatan diğer hastaların da yakınlarının olması, bu kişiler arasında etkileşim ve bilgi alışverişinin doğal olarak yoğun olması ve birbirlerine deneyimlerini aktarmaları olabileceği düşünüldü.

Puan sırasında en düşük ikinci bölüm "Hasta yakınının duygusalığına etki" bölümüdür. Hasta yakınlarından yarıya yakını hemşirelerin ve üçte biri doktorların o anki duygularıyla zayıf olarak ilgilendiğini belirtmişlerdir. Bu durum özellikle olumlu olarak değerlendirilebilecek yanıtların az olarak seçilmesi nedeniyle, hemşire ve doktorların hasta yakınlarının duygularıyla pek fazla ilgilenmediğini düşündürmektedir. Yapılmış diğer çalışmalara bakıldığında da çalışmamızdaki bulgulara paralel olarak hasta yakınları kendi intiyaçlarına gösterilen ilgi, duygusal destek, umut verme gibi alanlarda yoğun bakım ünitesinde çalışan hemşire ve doktorlardan zayıf düzeyde memnun bulunmuşlardır $(2,3,4,9,10,11,13)$. Bunun nedeni, tüm dünyada yoğun bakım ünitesi çalışanlarının hastaya odaklanmaları ve hasta yakınının ihtiyaçlarının geri planda kalması olabilir. Ancak buna rağmen çalışmamızda hasta yakınlarının hastaları ile ilgili kendilerini üzen ve sıkıntı duydukları konuları doktorlar ve hemşireler ile rahatlıkla konuştukları görülmüştür. Hasta yakınlarının yarıdan fazlası hastalarını ziyaret ederken kendilerini çok iyi ve iyi derecede rahat hissettiklerini belirtmişlerdir. Bunun nedeninin yoğun bakım ünitesinin doktor ve hemșirelerinin hasta yakınlarına hastaları ile ilgili konuları dile getirirken ilgili ve anlayışlı davranmaları olabileceği düşünüldü. Bu durum zaten anketimizin memnuniyet ile ilgili diğer bölümlerinde saptanmıştır.

En düşük puanların hesaplandığı ve buna oranla memnuniyetin en düşük bulunduğu bölüm "Bekleme ortamı ve lojistik destek" bölümüdür. Hasta yakınlarının yarıya yakını tarafından bekleme ortamı konfor bakımından zayıf bulunmuştur. Bu durum da bekleme ortamının olumsuzluğunu düşündürmektedir. Ayrıca hasta yakınlarının yarısı hastaları ile ilgili yoğun bakım ünitesi dışında yapılması gereken işlerle her zaman bizzat ilgilenmek zorunda kalmaktadırlar. Buna 
\%31,3 oranında "Çoğu zaman" yanııını da eklersek ciddi bir rahatsızlık olduğunu görmekteyiz. Ayrıca yapılmış çalışmalara bakıldığında tüm dünyada hasta yakınlarının yoğun bakım ünitelerinin bekleme salonlarından zayıf veya orta düzeyde memnun olduğu saptanmıștır $(3,4,11)$. Tüm bu bulgular değerlendirildiğinde yoğun bakım ünitelerimizin bekleme salonlarında iyileştirme yapılması gerektiği, ayrıca hasta yakınları yerine hastaların diğer birimlerde yapılması gereken tetkik ve görüntüleme gibi işlemlerini görevlendirilmiş personeller tarafından yapılması gerektiği sonucu çıkarılabilir.

Puanlamada beșinci sıradaki bölüm "Karar verme süreci" bölümüdür. Hasta yakınlarının verdikleri yanıtlara göre, büyük çoğunluğunun karar verme sürecine dahil edildiklerini, bu süreçte desteklendiklerini, hastalarının tedavi ve bakımları konusunda kontrol sahibi olduklarını hissettikleri ve bu süreçte endişelerinin giderilmesi, sorularının yanıtlanması ve bir karara varmaları için yeterli zamanın kendilerine tanındığı görülmektedir. Bu sonuçların, yoğun bakım ünitesinde çalışan ve bilgi veren doktorların hasta yakınlarına yaklaşımlarının ve aralarındaki iletişimin iyi olmasından, hasta yakınlarına yeterli ve anlaşılabilir bilgi vermelerinden, sorularına yeterli zamanı ayırmalarından kaynaklanabileceği düşünülmüştür. Heyland DK ve arkadaşlarının 2002 yılında yaptığı çalışmada da genel olarak karar verme süreci ile ilgili hasta yakınlarının memnuniyetleri yüksek bulunmuş, bu konunun hasta yakını ile iletişim ve yeterli, güvenilir ve anlaşılabilir bilgi verme ile birlikte genel memnuniyetin artmasında yüksek oranda etkili olduğu belirtilmiştir (11).

Çalışmamızda uygulanan ankette hasta yakınlarının yazarak cevap verebilecekleri "Hastanızı ziyaret ettiğinizde sizi rahatsı eden bir durumla karşılaştınız mı?" şeklinde bir soru da bulunmaktadır. Bu soru 19 hastanın yakını tarafından yanıtlanmıştır. Çalışmaya dahil edilen 211 hasta yakını düșünüldüğünde bu sayının çok düşük olduğu görülmektedir (\%9). Verilen yanıtlardan en çok rahatsızlık duyulan konuların başında hastaların üzerinde giysilerinin olmaması ve zaman zaman üstlerinin açık olması, özellikle ziyaretçilerin hijyen kurallarına uymasına yeterli özenin gösterilmediğinin düşünülmesi ve hastaların solunum sıkıntısı çektiğinin düşünülmesi gelmektedir. Bunlar dışında hasta yakınları hastalarının gözlerinin kapatılmasından, ellerinin ve ayaklarının bağlanmış olmasından, yoğun bakım ünitesindeki el dezenfektanının bozuk olmasından, çöp torbalarının yoğun bakım ünitesi içinde ortalıkta durmasından rahatsız olduklarını belirtmişlerdir. Karar vermek için yeterli sayı olmasa da seçilen anket grubunda yeteri kadar kritik hasta bilincinin olmadığı düşünülmüştür.

Çalışmamızda geriye dönük yaptığımız değerlendirmelerimizde anket hazırlığı aşamasında teknik destek almanın olumlu etkileri olabileceği düşünüldü. Memnuniyetin değerlendirilmesi dışında memnuniyete etki eden faktörler incelenebileceği, hasta yakını özellikleri yanında hastaların demografik özelliklerinin, tanılarının, prognozlarının, acil veya elektif olarak yoğun bakıma alınmış olmalarının, yatış sürelerinin çalışmaya eklenebileceği ve tüm bu özelliklerin memnuniyeti ne yönde etkileyeceği araştırılabilirdi. Ileride yapılabilecek çalışmalar planlanırken yatmakta olan hastaların yakınlarına aynı anketin iki farkı zamanda uygulanarak memnuniyet değerlerinde değişimin araştırılabileceği düşünüldü.

Sonuç olarak anketimizin içerdiği memnuniyet alt gruplarından bazılarını karşılaştırmak için literatürde yeteri kadar çalışma bulunamamıştır. Genel olarak bakıldığında hasta yakınlarııın yoğun bakım ünitesi çalışanlarından memnun oldukları görülmektedir. Ancak bir sağlık hizmetinin bütünleyicisi olan fiziki koşulların yetersizliği de çalışmamızla ortaya çıkmıştır.

\section{Çıkar Çatışması \\ Yazarlar herhangi bir çıkar çatışması bildirmemişlerdir.}

\section{Kaynaklar}

1. Heyland DK, Tranmer J. Measuring family satisfaction with care in the intensive care unit: The development of a questionnaire and preliminary results. The KGH ICU Research Working Group. J Crit Care 2001;16:142-9.

2-. Johnson D, Wilson M, Cavanaugh B, Bryden C, Gudmundson D, Moodley $\mathrm{O}$. Measuring the ability to meet family needs in an intensive care unit. Crit Care Med 1998;26:266-71.

3. Hunziker S, McHugh W, Sarnoff-Lee B, Cannistraro S, Ngo L, Marcantonio E, et al. Predictors and correlates of dissatisfaction with intensive care. Crit Care Med 2012;40:1554-65.

4. Stricker KH, Kimberger O, Schmidlin K, Zwahlen M, Mohr U, Rothen HU. Family satisfaction in the intensive care unit: What makes the difference? Intensive Care Med 2009;35:2051-9.

5. Wasser T, Pasquale MA, Matchett SC, Bryan Y, Pasquale M. Establishing reliability and validity of the Critical Care Family Satisfaction Survey. Crit Care Med 2001;29:192-6.

6. Dodek PM, Heyland DK, Rocker GM, Cook DJ. Translating family satisfaction data into quality improvement. Crit Care Med 2004;32:1922-7
7. Wall RJ, Engelberg RA, Downey L, Heyland DK, Curtis JR. Refinement, scoring, and validation of the Family Satisfaction in the Intensive Care Unit (FS-ICU) survey. Crit Care Med 2007;35:271-9.

8. Erden IA, Pamuk AG, Akıncı SB, Turgut HC, Sarıcaoğlu F, Aypar Ü. Yoğun bakım ünitesinde aile memnuniyetinin değerlendirilmesi. Türk Yoğun Bakım Der Dergisi 2010;8:18-25.

9. Dodek PM, Wong H, Heyland DK, Cook DJ, Rocker GM, Kutsogiannis DJ, et al. The relationship between organzational culture and family satisfaction in critical care. Crit Care Med 2012;40:1506-12. 
10. Azoulay E, Chevret S, Leleu G, Pochard F, Barboteu M, Adrie C, et al. Half the families of intensive care unit patients experience inadequate communication with physicians. Crit Care Med 2000;28:3044-9.

11. Heyland DK, Rocker GM, Dodek PM, Kutsogiannis DJ, Konopad E, Cook DJ, et al. Family satisfaction with care in the intensive care unit: Results of a multiple center study. Crit Care Med 2002;30:1413-8.
12. Akıncı SB, Salman N, Kanbak M, Aypar Ü. Yoğun bakımda aile memnuniyetinin değerlendirilmesi. Türk Anest Rean Der Dergisi 2004;32:130-8.

13. Myhren H, Ekeberg O, Langen I, Stokland O. Emotional strain, communication, and satisfaction of family members in the intensive care unit compared with expectations of the medical staff: experiences from a Norwegian University Hospital. Intensive Care Med 2004;30:1791-8 